\title{
Cutting ages of elephant grass for chopped hay production ${ }^{1}$
}

\author{
Eduardo André Ferreira ${ }^{2}$, Joadil Gonçalves de Abreu², \\ Junio Cesar Martinez ${ }^{3}$, Thiago Gomes dos Santos Braz ${ }^{4}$, Daniel Paulo Ferreira ${ }^{2}$
}

\begin{abstract}
With the advancement of the cutting age, there is an increase in the forage yield of elephant grass (Pennisetum purpureum), but there is also a reduction of the protein levels and digestibility of this forage. This study aimed to identify the ideal cutting age of elephant grass forage (BRS Canará cultivar) to chopped hay production. The experimental design was a randomized block, with five treatments $(42,60,76,91$ and 105 days of growing) and four replicates. Forage agronomical, morphological and chemical characteristics were evaluated. A linear positive effect of the cutting age was observed on plant height, senescent material and yield of the chopped hay. The leaf percentage and leaf:stem ratio were reduced by the advance in the cutting age. There was also a linear positive effect of the cutting ages on indigestible neutral detergent fiber, neutral detergent fiber corrected for ash and protein and neutral detergent insoluble protein, with increases of $17.13 \%, 16.63 \%$ and $20.66 \%$, respectively. The contents of ashes, crude protein, total digestible nutrients and net lactation energy were reduced with the advance in the forage age. From 76 days, the ashes contents reached values below $9.29 \%$ and the crude protein below $7.16 \%$. In the same cutting age, the chopped hay yield was $12.91 \mathrm{t} \mathrm{ha}^{-1}$. To improve the hay quality and production, the BRS Canará cultivar must be harvest between 60 and 76 days, when the plants are with $1.20-1.50 \mathrm{~m}$ of height, leaf:stem ratio of $0.55-0.44$, crude protein of $8.29-7.16 \%$ and indigestible neutral detergent fiber of $26.21-29.06 \%$.
\end{abstract}

KEYWORDS: Pennisetum purpureum; bromatologic composition; forage production; net energy.

\section{INTRODUCTION}

Seasonality in pastures is caused by low availability of growth factors, such as rainfall,

\begin{abstract}
RESUMO
Períodos de colheita de capim-elefante para produção de feno picado

Com o avanço da idade de corte, há aumento na produtividade da forragem de capim-elefante (Pennisetum purpureum), mas, também, redução nos teores de proteína e digestibilidade da forrageira. Objetivou-se determinar a época ideal de corte da forragem em capimelefante (cultivar BRS Canará), para a produção de feno picado. Utilizou-se delineamento experimental em blocos casualizados, com cinco tratamentos (42, 60, 76, 91 e 105 dias de crescimento) e quatro repetições. Foram avaliadas características agronômicas, morfológicas e químicas. Verificou-se efeito linear positivo do momento de colheita sobre a altura da planta, material senescente e produtividade do feno picado. Já a porcentagem de lâminas foliares e a relação folha:colmo reduziram-se, em função da idade de corte. A idade de corte também exerceu efeito linear positivo sobre a fibra em detergente neutro indigestível, fibra em detergente neutro corrigida para cinzas e proteína e proteína insolúvel em detergente neutro, com aumentos de $17,13 \%, 16,63 \%$ e 20,66 \%, respectivamente. Já os teores de cinzas, proteína bruta, nutrientes digestíveis totais e energia líquida de lactação diminuíram com o avanço da idade da forrageira. A partir de 76 dias, os teores de cinzas atingiram valores abaixo de $9,29 \%$ e a proteína bruta abaixo de $7,16 \%$. Nesta idade de corte, a produtividade de feno foi de 12,91 tha-1. Para melhorar a qualidade e a produção de feno, a cultivar BRS Canará deve ser cortada entre 60 e 76 dias, quando as plantas estão com 1,20-1,50 m de altura, relação folha:colmo de $0,55-0,44$, proteína bruta de $8,29-7,16 \%$ e fibra em detergente neutro indigestível de 26,21-29,06\%.
\end{abstract}

PALAVRAS-CHAVE: Pennisetum purpureum; composição bromatológica; produção de forragem; energia líquida.

temperature and photoperiod (Wang et al. 2017), during the off-season, and may affect negatively the pasture production and quality (Gurgel et al. 2017). In this situation, stored forages provide nutrients for

1. Manuscript received in Feb./2018 and accepted for publication in Jul./2018 (http://dx.doi.org/10.1590/1983-40632018v4851569).

2. Universidade Federal de Mato Grosso, Faculdade de Agronomia, Medicina Veterinária e Zootecnia, Departamento de

Zootecnia e Extensão Rural, Cuiabá, MT, Brasil. E-mail/ORCID: eduardoagritrop@gmail.com/0000-0002-1283-1093, joadil@terra.com.br/0000-0002-1355-5326, daniel.agromatogrosso@gmail.com/0000-0001-7722-6575.

3. Universidade do Estado de Mato Grosso, Departamento de Zootecnia, Pontes de Lacerda, MT, Brasil. E-mail/ORCID: martinez1178@hotmail.com/0000-0001-5323-1775.

4. Universidade Federal dos Vales do Jequitinhonha e Mucuri, Departamento de Zootecnia, Diamantina, MG, Brasil. E-mail/ORCID: thiagogsbz@hotmail.com/0000-0003-1840-7901. 
ruminants, when the pasture is inadequate (Silva et al. 2016). Alternatively, the hay production preserves the forage by a partial dehydration of fodder plants. This process inhibits the spoilage activity of microorganisms and plant enzymes, thus preserving the forage for long periods (Silva et al. 2016).

Elephant grass (Pennisetum purpureum) is one of the most widespread grasses in tropical and subtropical regions of the world. This plant has a high forage production and nutritive value, which make it important for cutting and carrying systems. In recent years, new elephant grass cultivars have been released for forage production (Pereira et al. 2017). The BRS Canará was released by the Embrapa in 2012, with characteristics of high plant height, late flowering, vegetative propagation and better development in fertile soils (Embrapa 2014).

Its use as chopped forage or silage is favored by the high plant height and yield (Santiago et al. 2015). However, the use of the BRS Canara for hay production may be negatively affected by the large size of the stems, which reduces the forage quality and loss of water during the dehydration process. An alternative to improve the elephant grass haymaking is chopping the forage prior to drying (Lima \& Maciel 1996). The damages caused by the cutting blade in the plant tissues accelerate the water loss (Lima \& Maciel 1996).

A linear effect of the cutting age on plant height was observed by Bhering et al. (2008), in Roxo elephant grass, as well as a quadratic effect for leaf blade percentage and leaf:stem ratio. Aguiar et al. (2006) assessed the production, chemical characteristics and losses of chopped hay of Cameroon elephant grass, with forage cutting at 60 days, and observed a yield of $6.9 \mathrm{t} \mathrm{ha}^{-1}$ per cutting, $6.76 \%$ to crude protein, $0.52 \%$ to neutral detergent insoluble protein, $90.65 \%$ to dry matter, $10.98 \%$ to ashes and $50.3 \%$ to total digestible nutrients.

Obtaining forage with high quality for chopped hay production depends on the identification of the most appropriate time for harvesting. Delaying the cutting age affects positively the yield of harvested forage, but reduces the cell contents (Sales et al. 2014). The progress of plant aging promotes the accumulation of more lignified tissues, dilutes the crude protein and decreases digestibility (Van Soest 1994). On the other hand, an early harvest may reduce significantly the forage production. Thus, the optimal cutting age for the elephant grass haymaking process must consider the balance among yield, agronomic characteristics and nutritional value of the forage. Therefore, this study aimed to determine the optimal cutting age of elephant grass (BRS Canará cultivar) for chopped hay production.

\section{MATERIAL AND METHODS}

The experiment was conducted at the Universidade Federal de Mato Grosso, in Santo Antônio do Leverger, Mato Grosso state, Brazil (15 $51^{\prime} 56^{\prime \prime} \mathrm{S}$ and $\left.56^{\circ} 04^{\prime} 36^{\prime \prime} \mathrm{W}\right)$, during the rainy season (October 2013 to February 2014). The climate is classified as Aw, characterized by a high average temperature and the occurrence of a dry winter (April to September) and rainy summer (October to February). During the trial period, the daily average temperature was $24.9-27.4{ }^{\circ} \mathrm{C}$, with $1,053 \mathrm{~mm}$ of accumulated rainfall (Figure 1). The soil at the experimental area was classified as a RedYellow Latosol (Embrapa 2006), or Oxisol (USDA 2014), with an outstanding A horizon and a flat relief. Soil samples (0-0.1 m depth) were collected to determine the physical and chemical profile (Table 1).

The choice of the BRS Canará cultivar is justified because it is recommended specifically for the Brazilian Savannah region, although its management for hay cutting and production has not

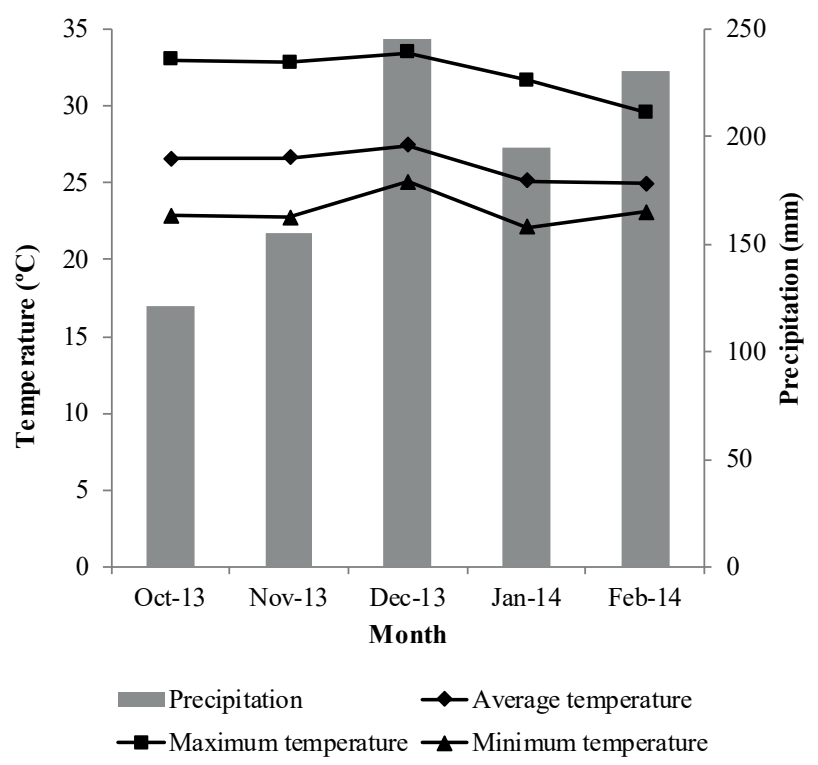

Figure 1. Monthly averages of rainfall $(\mathrm{mm})$ and minimum, average and maximum temperatures $\left({ }^{\circ} \mathrm{C}\right)$, during the trial period. 
Table 1. Soil chemical and physical properties (0-0.1 m depth).

\begin{tabular}{|c|c|c|c|c|c|c|c|c|c|c|}
\hline \multirow{2}{*}{$\mathrm{pH}\left(\mathrm{CaCl}_{2}\right)$} & $\mathrm{P}$ & $\mathrm{K}^{+}$ & $\mathrm{Ca}^{2+}$ & $\mathrm{Mg}^{2+}$ & $\mathrm{H}+\mathrm{Al}$ & $\mathrm{Al}^{3+}$ & \multirow{2}{*}{$\frac{\mathrm{OM}}{\mathrm{g} \mathrm{dm}^{-3}}$} & Clay & Silt & Sand \\
\hline & \multicolumn{2}{|c|}{$\mathrm{mg} \mathrm{dm}^{-3}$} & - & $-\mathrm{c}$ & $\mathrm{dm}^{-3}$ & & & \multicolumn{3}{|c|}{$\mathrm{g} \mathrm{kg}^{-1}$} \\
\hline 5.5 & 6.6 & 84.0 & 2.7 & 1.0 & 2.2 & 0.0 & 11.8 & 227.0 & 66.0 & 707.0 \\
\hline
\end{tabular}

P and K: Mehlich-1; Ca, Mg and Al: KCl 1 mol L-1; $\mathrm{H}+\mathrm{Al}$ : SMP; OM: oxidation $\mathrm{Na}_{2} \mathrm{Cr}_{2} \mathrm{O}_{7} 0.67 \mathrm{~mol} \mathrm{~L}^{-1}+\mathrm{H}_{2} \mathrm{SO}_{4} 5 \mathrm{~mol} \mathrm{~L}^{-1}$; sand, silt and clay: pipette method.

been properly standardized yet. The experimental field was established in March 2013, using $90 \mathrm{~kg} \mathrm{ha}^{-1}$ of $\mathrm{P}_{2} \mathrm{O}_{5}$ and super simple phosphate. In November 2013, the grass was cut uniformly at a height of $0.10 \mathrm{~m}$ from de ground. Then, $100 \mathrm{~kg} \mathrm{ha}^{-1}$ of $\mathrm{N}$ and $100 \mathrm{~kg} \mathrm{ha}^{-1}$ of $\mathrm{K}_{2} \mathrm{O}$ were applied, using the formula 20-05-20.

The experimental design was a randomized complete block, with five treatments (cutting ages: 42, 60, 76, 91 and 105 days) and four replications. Each plot was $5.00 \mathrm{~m}$ long and $4.00 \mathrm{~m}$ wide, with a spacing of $1.00 \mathrm{~m}$ between rows. The data were collected in the two central rows of the plot, disregarding $1.0 \mathrm{~m}$ of border.

For each cutting age, the forage agronomic and morphological characteristics were evaluated using six tillers. The agronomic variables evaluated were: plant height, measured from the soil surface to the insertion point of the last fully expanded leaf; leaf blade length, using the last fully expanded leaf of each tiller; leaf blade width, measured in the middle of the last fully expanded leaf; and stem diameter, measured at the ground level of the tiller base.

For determining the morphological composition, the tillers were separated into leaf blade, stem (stem + sheath) and senescent material (more than $50 \%$ of dead leaf blade). Each component was dried in a forced air circulation oven with an average temperature of $55-60{ }^{\circ} \mathrm{C}$, until constant mass. Subsequently, each component was weighed to obtain the leaf blade percentage, stem percentage, senescent material and leaf:stem ratio.

To biomass quantification, the plants in the useful area of each plot were cut, weighed and chopped to an approximate size of $2.00 \mathrm{~cm}$. The material was exposed to the sun on a black plastic up to the hay point (80-90\% of dry matter). At the end of the dehydration process, the chopped hay was removed from the black bag and weighed to determine the hay yield. Chopped samples of forage and hay were collected and dried in a forced air circulation oven with an average temperature of 55-60 ${ }^{\circ} \mathrm{C}$, until constant mass.

The forage and hay samples were ground in a Wiley mill and analyzed to: dry matter, ashes and crude protein (AOAC 1990; method 990.03); neutral detergent insoluble protein (Licitra et al. 1996); indigestible neutral detergent fiber (Cochran et al. 1986); and neutral detergent fiber corrected to ash and protein (Sniffen et al. 1992). The total digestible nutrient [total digestible nutrient $=88.9$ - $($ acid detergent neutral $x$ 0.779)] was estimated according to Cappelle et al. (2001) and the net lactation energy [net lactation energy $=2.39-($ acid detergent neutral $x$ 0.028)] according to David (2001). The neutral detergent insoluble protein was expressed in percentage of total dry matter and percentage of crude protein. Table 2 summarizes the forage chemical composition resulting from these analyses.

Data were statistically analyzed by analyses of variance and regression, at $5 \%$ of significance, using the SAEG statistical software. The graphs presented and used to determine the cutting age were elaborated through the standardization of the scales of the main variables, obtaining a ratio based on the division of the highest value.

Table 2. Chemical composition of the elephant grass BRS Canará cultivar at different cutting ages before haying.

\begin{tabular}{lrrrrr}
\hline \multirow{2}{*}{ Variable } & \multicolumn{5}{c}{ Cutting ages (days) } \\
\cline { 2 - 6 } & \multicolumn{1}{c}{42} & \multicolumn{1}{c}{60} & \multicolumn{1}{c}{76} & \multicolumn{1}{c}{91} & \multicolumn{1}{c}{105} \\
\hline DM & 18.90 & 20.73 & 21.89 & 23.40 & 26.35 \\
Ash & 12.31 & 10.57 & 9.44 & 8.92 & 7.69 \\
iNDF & 20.16 & 24.99 & 28.13 & 35.06 & 36.02 \\
apNDF & 57.70 & 62.18 & 64.61 & 70.46 & 73.38 \\
CP & 11.93 & 9.12 & 8.10 & 7.18 & 6.03 \\
NDIP-DM & 3.52 & 3.28 & 3.27 & 3.22 & 3.17 \\
NDIP-CP & 29.64 & 35.89 & 40.22 & 44.74 & 52.77 \\
TDN & 57.22 & 56.16 & 55.50 & 52.86 & 51.10 \\
NLE & 1.25 & 1.21 & 1.19 & 1.09 & 1.03 \\
\hline
\end{tabular}

DM: dry matter (\%); Ash: ashes (\% DM); iNDF: indigestible neutral detergent fiber (\% DM); apNDF: neutral detergent fiber corrected for ash and protein ( $\% \mathrm{DM})$; CP: crude protein (\% DM); NDIP-DM: neutral detergent insoluble protein $(\%$ DM); NDIP-CP: neutral detergent insoluble protein (\% CP); TDN: total digestible nutrients $(\% \mathrm{DM})$; NLE: net lactation energy $\left(\mathrm{Mcal} \mathrm{kg}^{-1}\right)$. 


\section{RESULTS AND DISCUSSION}

The morphological composition and agronomic characteristics of the elephant grass BRS Canará and the chopped hay yield were influenced by the cutting age (Figures 2, 3 and 4).

At the first cutting age (42 days), the elephant grass BRS Canará presented a plant height of $64.37 \mathrm{~cm}$, leaf blade lenght of $93.79 \mathrm{~cm}$, leaf blade width of $3.35 \mathrm{~cm}$, leaf blade percentage of $50.48 \%$, stem percentage of $49.51 \%$, senescent material percentage of $0.00 \%$ and leaf:stem ratio of 1.02. These values show that, at this cutting age, the grass presented a good leaf:stem ratio and an excellent leaf blade percentage, with better results for the ruminant diet, but a low chopped hay yield (4.77 $\left.\mathrm{t} \mathrm{ha}^{-1}\right)$.

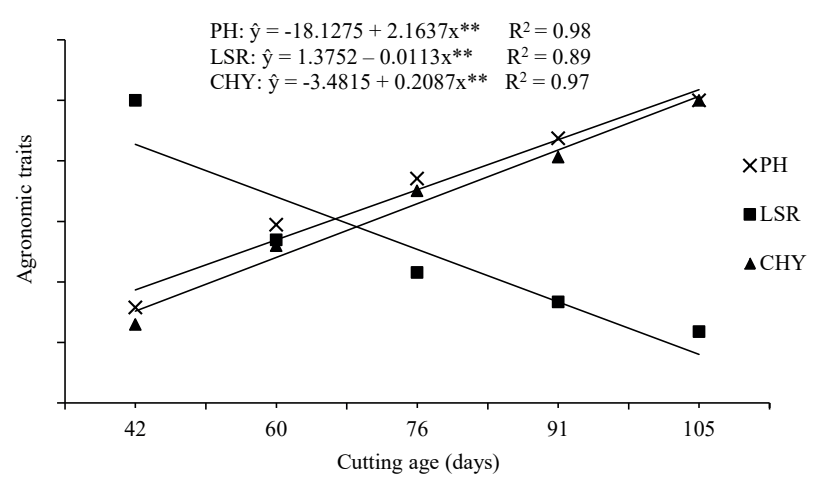

Figure 2. Plant height $(\mathrm{PH} ; \mathrm{cm})$, leaf:stem ratio (LSR) and chopped hay yield (CHY; $\left.\mathrm{t} \mathrm{ha}^{-1}\right)$ of the elephant grass BRS Canará at different cutting ages (** significant at $5 \%$ of probability, by the F-test).

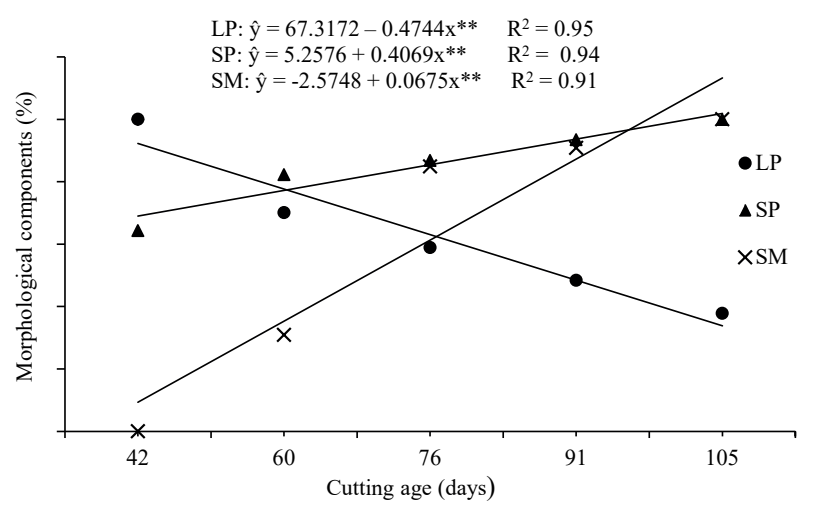

Figure 3. Leaf blade percentage (LP), stem percentage (SP) and senescent material percentage (SM) of the elephant grass BRS Canará at different cutting ages (** significant at $5 \%$ of probability, by the F-test).
At the second cutting age (60 days), there was a plant height of $120.25 \mathrm{~cm}$, which represents a strong increase, in relation to the first cutting age, and the elephant grass presented a leaf blade length of $118.95 \mathrm{~cm}$, leaf blade width of $4.46 \mathrm{~cm}$, leaf blade percentage of $35.39 \%$, stem percentage of $63.34 \%$, senescent material percentage of $1.25 \%$ and leaf:stem ratio of 0.55 . The strong increase of the grass plant height resulted in a higher stem percentage, which reduces the plant quality, but it is positively correlated with the increase of hay yield, which reached $9.57 \mathrm{t} \mathrm{ha}^{-1}$.

At 76 days, in the third cutting age of the elephant grass, a plant height of $151.37 \mathrm{~cm}$, leaf blade length of $122.16 \mathrm{~cm}$, leaf blade width of $4.42 \mathrm{~cm}$, leaf blade percentage of $29.75 \%$, stem percentage of $66.81 \%$, senescent material percentage of $3.43 \%$, leaf:stem ratio of 0.44 and chopped hay yield of $12.91 \mathrm{t} \mathrm{ha}^{-1}$ were observed. At this age, the leaf blade width became smaller than in the second cutting age. This tendency occurs because, as the competition for light increases among tillers, the stem elongation intensifies, and the plant starts to emit new leaves in the higher parts of the canopy, which are smaller in size, to allow the tiller balance.

With 91 days, in the fourth cutting age, the elephant grass presented a plant height of $178.45 \mathrm{~cm}$, leaf blade length of $111.08 \mathrm{~cm}$, leaf blade width of $4.34 \mathrm{~cm}$, leaf blade percentage of $24.41 \%$, stem percentage of $71.91 \%$, senescent material percentage of $3.67 \%$, leaf:stem ratio of 0.34 and chopped hay yield of $14.96 \mathrm{tha}^{-1}$. At this cutting age, the leaf blade length decreased, relatively to the third cutting age, following the same trend for leaf width presented in

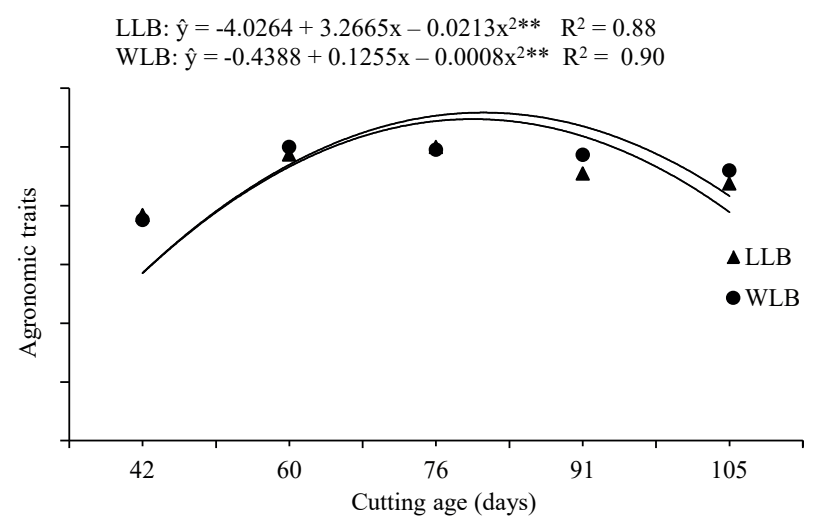

Figure 4. Leaf blade length (LLB; cm) and width (WLB; cm) of the elephant grass BRS Canará at different cutting ages (** significant at $5 \%$ of probability, by the F-test). 
the third cutting age. The other variables, however, maintained the trends observed in the previous cutting ages.

In the fifth and final cutting age, at 105 days, the plant height was $204.12 \mathrm{~cm}$, leaf blade length was $107.00 \mathrm{~cm}$, leaf blade width was $4.10 \mathrm{~cm}$, leaf blade percentage was $19.07 \%$, stem percentage was $76.88 \%$, senescent material percentage was $4.04 \%$, leaf:stem ratio was 0.24 and chopped hay yield was $18.42 \mathrm{t} \mathrm{ha}^{-1}$. At the last evaluated age, the elephant grass presented the lowest leaf percentage and the highest stem percentage, which resulted in the lowest leaf:stem ratio. The reduction of the leaf component tends to decrease the quality of the forage and, consequently, of the material to be conserved, since the leaf is the component with the highest contents of digestible protein. In addition, the tendency to reduce the leaf blade length and width observed in the previous cutting ages continued in the 105th day of evaluation, reinforcing the justification presented.

There was a linear increased relationship between the cutting age and the plant height, stem percentage, senescent material percentage and hay yield, with daily increases of $2.16 \mathrm{~cm}, 0.40 \%$, $0.06 \%$ and $0.21 \mathrm{t} \mathrm{ha}^{-1}$ of dry matter, respectively. The highest values found for plant height and hay yield in the most advanced cutting ages were justified by the fact that plants had more time to accumulate biomass. In addition, these results may be explained by the competition for light, which promotes the stem elongation and thickening, as a morphological mechanism to positioning the leaves on the top of the canopy and facilitate the light interception.

The stem fraction has a great importance in the production of elephant grass hay, since the management affects tillering and, consequently, the diameter of the stems. It is known that thin stems have a greater dehydration capacity, if compared to thicker ones. Thus, fertilization and irrigation strategies may contribute significantly to the production of elephant grass hay of higher bromatological quality.

There was a negative linear relationship between the cutting age and the leaf blade percentage and leaf:stem ratio, with a daily reduction of $0.47 \%$ and 0.01 , respectively. These results were already expected, since, as the plant develops, the stem elongation intensifies and the proportion of the stem fraction increases in the canopy (Carvalho et al. 2018).
The leaf blade length and width adjusted better to the quadratic model with maximum values of $121.20 \mathrm{~cm}$ and $4.54 \mathrm{~cm}$, after 77 and 79 days, respectively. Based on the results obtained, it was observed that the leaf length increases with the advance of the plant development up to a maximum point, from which it begins to decrease, as a function of the elevation of the apical meristem. This pattern is also related to the adaptation of the canopy architecture, as a tool for guaranteeing a greater photosynthetic efficiency of the leaves without compromising the structural balance of the plant.

The analysis of the measured agronomic traits indicates that ages between 60 and 76 days represent the most suitable cutting window to produce elephant grass BRS Canará chopped hay. At this age, the elephant grass presented the highest values for leaf blade length $(118.95-122.16 \mathrm{~cm})$ and width $(4.46-4.42 \mathrm{~cm})$. These agronomic traits are of great importance to assist in the determination of the ideal cutting time for the elephant grass. According to Van Soest (1994), these characteristics are highly correlated with the levels of crude protein and digestibility. Thus, higher leaf:stem ratios result in forage with a better nutritional value.

Leaves are the fraction of the forage plant with higher digestibility, being richer in crude protein, with a lower fiber content (Van Soest 1994). In the interval between 60 and 76 days, the elephant grass presented the best leaf yield, with 35.39-29.75\% for leaf blade and 9.57-12.91 $\mathrm{t} \mathrm{ha}^{-1}$ for hay yield. These agronomic traits evaluated together show that this range is characterized as the most opportune moment for the elephant grass cutting for hay production.

These increases at older ages were already expected, as the plant grows and recovers the leaf area and the intraspecific competition for light increases progressively, diminishing both the quantity and quality of light that penetrates the canopy. To adapt to competition for light, the plant begins to invest in stem elongation, to allocate its leaves at the top of its structure. Moreover, this response is followed by the elevation of the apical meristem, which reduces the distance that the new leaf must travel inside the stem and, thus, subsequently reduces the leaf blade length of the new emerging leaves.

Similar studies reported an increase in plant height and hay yield and a reduction in the leaf blade percentage, if compared to the leaf:stem ratio, with advances in the elephant grass cutting age (Bhering 
et al. 2008). According to Van Soest (1994), the leaf:stem ratio is of great importance for animal nutrition, being associated with the ease of feeding the most nutritious parts of the forage plant.

The highest values found for the leaf blade percentage in younger plants may have occurred due to the plant development stage. At this stage, the plant is in a full vegetative development and prioritizes the leaf elongation to increase its photosynthetic capacity, thus accelerating its growth and restoring the leaf area after cutting. A high leaf blade percentage is important to the hay making process, because the leaves improve the hay chemical composition and the dehydration process (Pinho et al. 2013).

The increase in the percentage of stems observed in the most advanced cutting ages involves spending energy for the growth and maintenance of this fraction, which negatively influences the forage nutritional value (Van Soest 1994). In addition, the stem has a lower dehydration rate, in relation to the leaves, allowing longer periods of cell respiration for plants and microorganisms (Pinho et al. 2013).

The increase in the cutting age influenced all the characteristics of the nutritional value. The detergent fiber, neutral detergent fiber corrected for ash and protein and neutral detergent insoluble protein (\% of crude protein) increased with the development of the elephant grass, presenting a linear response to the cutting age. On the other hand, there was a reduction in the contents of ashes, crude protein, neutral detergent insoluble protein ( $\%$ of dry matter), total digestible nutrients and net lactation energy (Figure 5).

The reduction in the ash content (4.97\%), which represents $41.75 \%$ of the total (Figure 6 ), may cause a mineral deficiency and affect negatively the animal performance and health (Van Soest 1994). An ash content of $9.61 \%$ was observed in chopped hay from the elephant grass cut at 50 days (Camurça et al. 2002). The evaluation of the chopped hay production of the Cameroon elephant grass yielded an ash content of $11.14 \%$ (Aguiar et al. 2006).

The increase in fiber was likely due to the increased stem percentage and thickening of the cell wall with the cutting age. These fibers reduce the crude protein and slow the degradation and disappearance of digesta in the rumen (Machado et al. 2008). These fibers are structural carbohydrates used as an energy source by the rumen microorganisms (Van Soest 1994). The fiber contents are negatively related to the forage digestibility, because the increase in structural components of the cell wall reduces the passage rate in ruminants (Van Soest 1994).

The indigestible neutral detergent fiber is a way to study the fiber quality. In the late harvest, it increases the indigestible neutral detergent fiber content and reduces the digestibility of the fiber and some parts of the protein. Increases of $17.13 \%$ and $16.63 \%$ were observed for indigestible neutral detergent fiber and neutral detergent fiber corrected

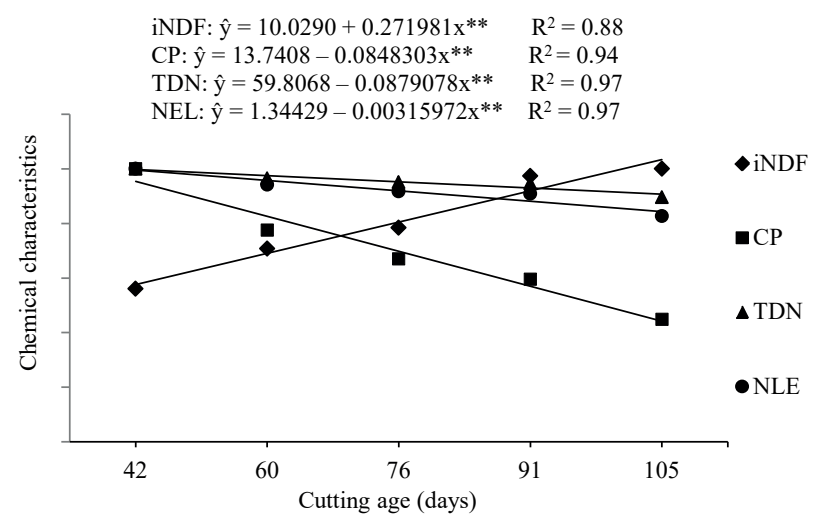

Figure 5. Chemical composition of chopped hay from the elephant grass BRS Canará at different cutting ages (iNDF: indigestible neutral detergent fiber, in \% of dry matter; $\mathrm{CP}$ : crude protein, in \% of dry matter; TDN: total digestible nutrients, in $\%$ of dry matter; and NLE: net lactation energy, in $\mathrm{Mcal} \mathrm{kg}^{-1}$; ** significant at $5 \%$ of probability, by the F-test).

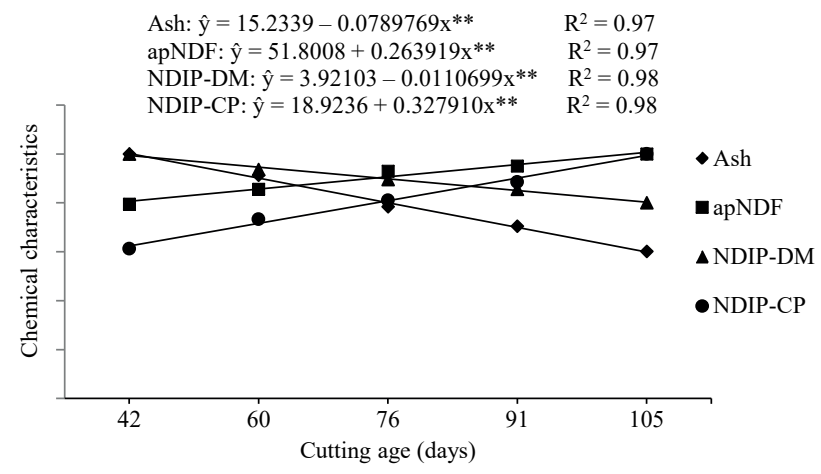

Figure 6. Chemical composition of chopped hay from the elephant grass BRS Canará at different cutting ages (Ash: ashes, in \% of dry matter; apNDF: neutral detergent fiber corrected for ash and protein, in $\%$ of dry matter; NDIP-DM: neutral detergent insoluble protein, in \% of dry matter; NDIP-CP: neutral detergent insoluble protein, in \% of crude protein; ** significant at $5 \%$ of probability, by the F-test). 
for ash and protein content, which represent $79.87 \%$ and $24.44 \%$ of the totals, respectively. The increase in the indigestible neutral detergent fiber content may contribute to reduce the dry matter intake by cattle (Machado et al. 2008).

Digestibility and forage intake are also limited by low crude protein, resulting in low animal productivity. An increased cutting age caused a reduction of $5.35 \%$ in this variable, which represents $52.51 \%$ of the total. For up to 79 days, the chopped hay from elephant grass presented a protein content higher than the minimum value recommended for the development of cellulolytic bacteria: $7 \%$ (Van Soest 1994). Values below $7 \%$ reduce the activity of rumen microorganisms and decrease the use of neutral detergent fiber. Crude protein contents of $6.68 \%$ were found by Camurça et al. (2002), in chopped hay from elephant grass cut at 50 days, and levels up to $7.59 \%$ by Aguiar et al. (2006), with a grass cut at 60 days.

With the increase in the cutting age, there was a reduction in the neutral detergent insoluble protein (\% in dry matter) of $0.70 \%$, which represents $20.18 \%$ of the total. A level of $0.52 \%$ on this variable was observed for chopped hay from Cameroon elephant grass cut at 60 days (Aguiar et al. 2006). On the other hand, the fraction of neutral detergent insoluble protein in the crude protein increased with the cutting age (Figure 5). These results are related to the advance of the canopy development, which, in addition to raising the cell wall content, also increased the protein associated with the fiber indigestible fractions.

The effect of late cutting ages reducing the cellular content and increasing the indigestible fibrous fractions reduces the total digestible nutrients content and net lactation energy. Reducing these factors may reflect in a reduction in the animal performance and a lower feed conversion efficiency.

The dry matter accumulation capacity is remarkable (4.77 tha ${ }^{-1}$ at 42 days versus $12.91 \mathrm{t} \mathrm{ha}^{-1}$ at 76 days). On the other hand, although a reduction in the bromatological quality is observed, such reduction does not significantly affect traits such as crude protein, total digestible nutrients, indigestible neutral detergent fiber and net lactation energy, thus demonstrating a maintenance of desirable characteristics in the stem fraction, since the leaf:stem ratio decreases in this period. Such behavior is not observed in this same intensity for other grasses, like the Brachiaria and Panicum genera.
Due to the large increase in the fiber components and the reduced ash content and protein with the advance of the cutting age, it is recommended that the elephant grass BRS Canará should be harvested between 60 and 76 days, because, at these ages, the grass has a good balance of the main chemical characteristics of the chopped hay (Figure 3). At these ages, the elephant grass should be $1.20 \mathrm{~m}$ and $1.50 \mathrm{~m}$ tall, respectively. These heights are close to the traditionally proposed values, which recommend that the elephant grass be cut at $1.80 \mathrm{~m}$ during the rainy season or $1.50 \mathrm{~m}$ in the dry season (Gomide 1997). Thus, it would be possible to avoid an overextension of the stem and balance the fiber and ash content, promoting a better chopped hay nutritional value for the animal.

During the evaluation, reductions of $5.54 \%$ and $0.20 \mathrm{Mcal} \mathrm{kg}^{-1}$ in the total digestible nutrients content and net lactation energy, which represent $9.87 \%$ and $16.43 \%$ of the totals, respectively, were observed. A total digestible nutrients content of $54.33 \%$ was observed in chopped hay from Cameroon elephant grass cut at 60 days (Aguiar et al. 2006), which is lower than the value found in this study at the same time (54.15\%).

The net lactation energy requirements depend on the lactation and gestation stage of the animal, which ranges 1.35-1.47 Mcal kg-1 for dry cows (at the beginning of the period) and 2.18-2.23 $\mathrm{Mcal} \mathrm{kg}^{-1}$ for newly calved cows (0-21 days) (USA 2001). Likewise, the total digestible nutrients requirement may vary $60-65 \%$ for dry cows (early period) and $94-96 \%$ of the total digestible nutrients for newly calved cows (0-21 days).

Overall, the results demonstrate the great potential of the elephant grass for conservation purposes, in the form of chopped hay, being characterized as a good alternative to ruminants during the dry season. However, as the intervals among the cutting ages might determine the nutritional value of the chopped hay, the cutting age may vary according to the relevant climate conditions in each region. This is very important, considering that the elephant grass presents a quick accumulation of stems, thus consequently reducing its nutritional value.

Although evaluations related to climate and soil data have not been carried out, it is believed that there were no nutritional, water or luminosity limitations in the elephant grass development, and no type of deficiency or stress was evidently verified 
during the evaluated cycle. However, it is known that, in many regions, these limitations may interfere in the plant development, thus reducing the forage yield and quality.

\section{CONCLUSIONS}

The BRS Canará elephant grass should be cut between 60 and 76 days to the chopped hay production. At this period, the plants are with 1.20 $1.50 \mathrm{~m}$ of height, leaf:stem ratio of $0.55-0.44$, crude protein of $8.29-7.16 \%$ and indigestible neutral detergent fiber of 26.21-29.06\%.

\section{ACKNOWLEDGMENTS}

The authors would like to thank the Conselho Nacional de Desenvolvimento Científico e Tecnológico (CNPq).

\section{REFERENCES}

AGUIAR, E. M. et al. Rendimento e composição químicobromatológica de fenos triturados de gramíneas tropicais. Revista Brasileira de Zootecnia, v. 35, n. 6, p. 2226-2233, 2006.

ASSOCIATION OF OFFICIAL ANALYTICAL CHEMISTS (AOAC). Official methods of analysis of the AOAC International. 15. ed. Arlington: AOAC Internacional, 1990.

BHERING, M. et al. Características agronômicas do capim-elefante Roxo em diferentes idades de corte na depressão cuiabana. Revista Brasileira de Saúde e Produção Animal, v. 9, n. 3, p. 384-396, 2008.

CAMURÇA, D. A. et al. Desempenho produtivo de ovinos alimentados com dietas à base de feno de gramíneas tropicais. Revista Brasileira de Zootecnia, v. 31, n. 5, p. 2113-2122, 2002.

CAPPELLE, E. R. et al. Estimativas do valor energético a partir de características químicas e bromatológicas dos alimentos. Revista Brasileira de Zootecnia, v. 30, n. 6, p. 1837-1856, 2001.

CARVALHO, A. P. S. et al. Agronomic features of elephant grass (Pennisetum purpureum Schum) cv. Roxo under irrigation. Semina: Ciências Agrárias, v. 39, n. 1, p. $275-$ 286, 2018.

COCHRAN, R. C. et al. Predicting digestibility of different diets with internal markers. Journal of Animal Science, v. 63, n. 5, p. 1476-1483, 1986.
DAVID, F. M. Composição e degradabilidade, através da técnica de produção de gás, de quatro gramíneas tropicais submetidas a corte em diferentes idades. $110 \mathrm{f}$. 2001. Dissertação (Mestrado em Zootecnia) - Universidade Federal de Lavras, Lavras, 2001.

EMPRESA BRASILEIRA DE PESQUISA AGROPECUÁRIA (Embrapa). Centro Nacional de Pesquisas de Solos. Sistema brasileiro de classificação de solos. 2. ed. Rio de Janeiro: Embrapa Solos, 2006.

EMPRESA BRASILEIRA DE PESQUISA AGROPECUÁRIA (Embrapa). Transferindo tecnologia e conhecimento a serviço da sociedade. Juiz de Fora: Embrapa Gado de Leite, 2014.

GOMIDE, J. A. Formação e utilização de capineira de capim-elefante. In: CARVALHO, M. M. et al. (Eds.). Capim-elefante: produção e utilização. 2. ed. Brasília, DF: Embrapa, 1997. p. 79-112.

GURGEL, A. L. C. et al. Estrutura do pasto e desempenho de ovinos em capim-massai na época seca em resposta ao manejo do período das águas. Boletim de Indústria Animal, v. 74, n. 2, p. 86-95, 2017.

LICITRA, G.; HERNANDEZ, T. M.; VAN SOEST, P. J. Standardization of procedures for nitrogen fractionation of ruminant feeds. Animal Feed Science and Technology, v. 57, n. 4 , p. $347-358,1996$.

LIMA, G. F. C.; MACIEL, F. C. Fenação e ensilagem: estratégias de armazenamento de forragens no Nordeste. In: SIMPÓSIO NORDESTINO DE ALIMENTAÇÃO DE RUMINANTES, 6., 1996, Natal. Anais... Natal: UFRN/ Emparn, 1996. p. 3-31.

MACHADO, P. A. S. et al. Avaliação nutricional do capimelefante (Cameroon) em diferentes idades de rebrotação. Revista Brasileira de Zootecnia, v. 37, n. 6, p. 1121-1128, 2008.

PEREIRA, A. V.; LÉDO, F. J. S.; MACHADO, J. C. BRS Kurumi and BRS Capiaçu: new elephant grass cultivars for grazing and cut-and-carry system. Crop Breeding and Applied Biotechnology, v. 17, n. 1, p. 59-62, 2017.

PINHO, R. M. A. et al. Avaliação de fenos de capim-buffel colhido em diferentes alturas de corte. Revista Brasileira de Saúde e Produção Animal, v. 14, n. 3, p. 437-447, 2013.

SALES, E. C. J. et al. Morphogenesis and productivity of Pioneiro elephant grass under different residual heights and light interceptions. Acta Sciences, v. 36, n. 2, p. $137-$ 143, 2014.

SANTIAGO, A. D.; MARAFON, A. C.; CAMARA, T. M. M. Espaçamentos de capim-elefante cultivado para fins energéticos nos Tabuleiros Costeiros de Alagoas. Aracaju: Embrapa Tabuleiros Costeiros, 2015. (Comunicado técnico, 176). 
SILVA, G. M. et al. Avaliação de forrageiras tropicais: revisão. Pubvet, v. 10, n. 3, p. 190-196, 2016.

SNIFFEN, C. J. et al. A net carbohydrate and protein system for evaluating cattle diets: II. Carbohydrate and protein availability. Journal of Animal Science, v. 70, n. 11, p. 3562-3577, 1992.

UNITED STATES DEPARTMENT OF AGRICULTURE (USDA). Keys to soil taxonomy. 12. ed. Washington, DC: USDA-Natural Resources Conservation Service, 2014.
USA. National Research Council. Nutrient requirements of dairy cattle. 7. ed. Washington, DC: National Academic Press, 2001.

VAN SOEST, P. J. Nutritional ecology of the ruminant. Ithaca: Comstock Publishing Associates, 1994.

WANG, S. et al. Responses of net primary productivity to phenological dynamics in the Tibetan Plateau, China. Agricultural and Forest Meteorology, v. 232, n. 1, p. 235246, 2017. 